\title{
Research connects soil hydrology and stream water chemistry in California oak woodlands
}

\author{
by Anthony T. O'Geen, Randy A. Dahlgren, \\ Alexandre Swarowsky, Kenneth W. Tate, David \\ J. Lewis and Michael J. Singer
}

\section{The UC Sierra Foothill Research and} Extension Center (SFREC) is located in the heart of typical California blue oak and live oak woodlands within metavolcanic terrain of the Sierra Nevada foothills. These types of woodlands often exist at the interface between urban, wild and agricultural lands and are used extensively for livestock grazing, wildlife habitat and surface water supply. Soil surveys for this region and within SFREC depict relatively few soil types compared to areas that support more-intensive agricultural land uses. Despite this inferred homogeneity, our study showed that the biogeochemical and physical properties of soils vary sharply over short distances of less than 10 feet and also experience changes by season and as a result of storm events. An understanding of soil variability in this setting is important to assess rangeland productivity, perennial grass and oak restoration potential, carbon sequestration, stream flow generation and stream water chemistry.

O ak woodlands are a patchy array of open grassland and oak canopy. The presence or absence of trees is one factor that imposes spatial variability in soil characteristics. Oak trees change the properties of soils beneath their canopies through a variety of nutrient-cycling processes, such as annual inputs of litter fall (Dahlgren et al. 2003). As leaves drop and decompose at the soil surface, organic matter and nutrients are resupplied to the upper soil horizons, creating islands of fertility and enhanced soil

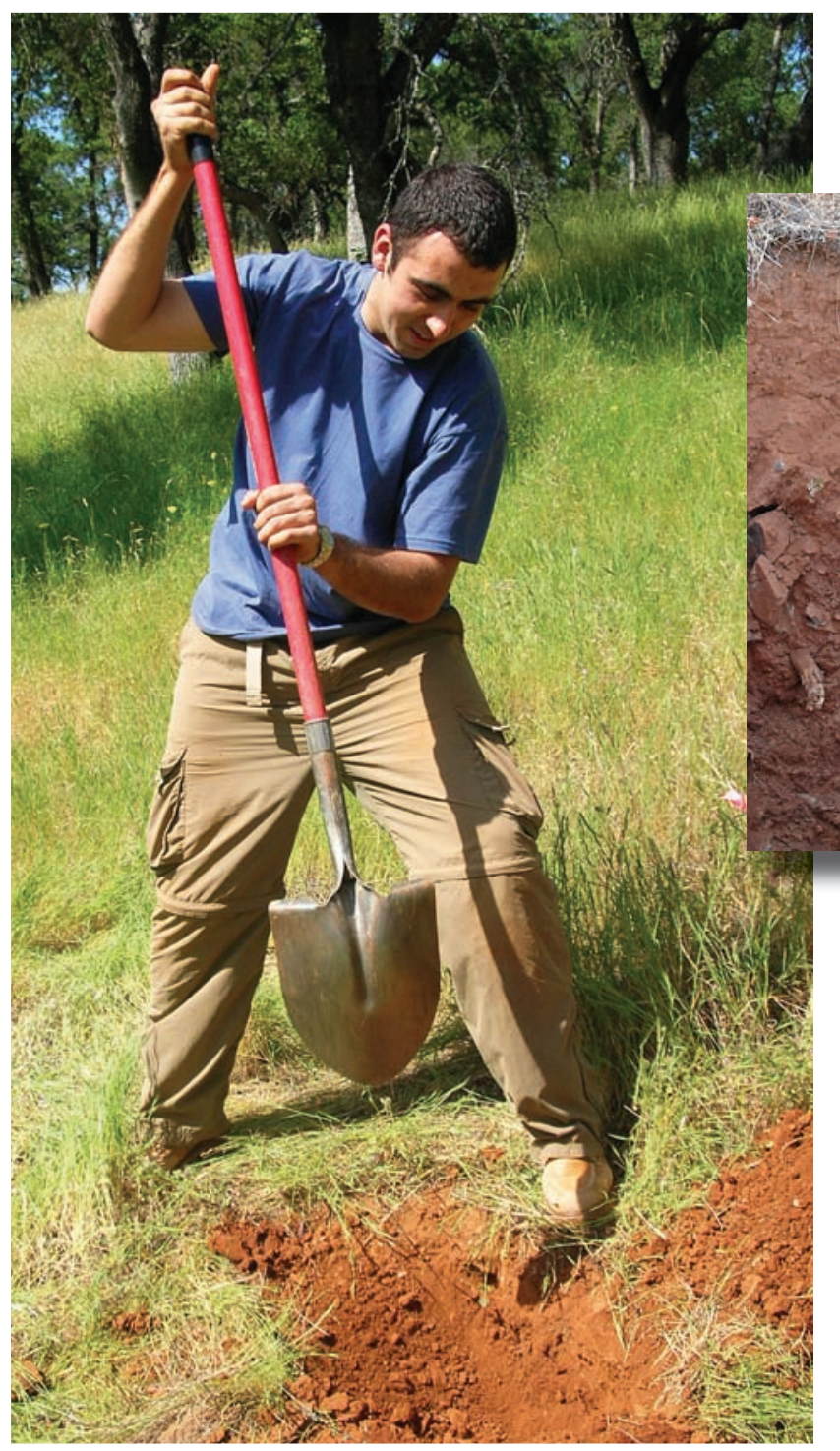

UC Davis undergraduate Tony Orozco installs a sensor in the Lewis-1 watershed at the UC Sierra Foothill Research and Extension Center.

quality. Physical (bulk density, water infiltration rates), chemical (nutrient enrichment, $\mathrm{pH}$, cation exchange capacity) and biological (microbial biomass, soil respiration) properties are enhanced in soils under oak canopies (Dahlgren et al. 1997). In contrast, soils forming under annual grasses in the absence of oak canopy are less fertile, have higher bulk density and are more susceptible to surface-water runoff.

Soil processes exhibit unique patterns in Mediterranean ecosystems such as California, due to the timing of precipitation. Summers are warm and dry, and most of the rain falls in winter months when vegetation is dormant and the temperature is low. Most biogeochemical processes require hospitable temperatures and an adequate water supply. Interactions between the ecosystem services that soils provide, such as nutrient cycling and the regulation of water quality and quantity, are strongly influenced by the seasonality of climate and individual storm events. 
Together, (1) the Mediterranean climate, (2) the inferred spatial homogeneity of soils and (3) oak tree-induced differences in soil properties, pose an interesting challenge for understanding the ecosystem services that soils provide and subsequent management implications.

Our primary objective was to examine the linkages between nitrogen cycling and soil hydrology in a manner that considers how the temporal and spatial variability of soil properties govern these processes and ultimately the soil's ability to regulate stream water quantity and quality in oak woodlands. We present results from multiple longterm monitoring projects at the UC Sierra Foothill Research and Extension Center (SFREC) that integrate soil, ecology and water-resources data from the area's California blue oak (Quercus douglasii) and live oak (Q. wislizeni) wood-

\section{Glossary}

Biogeochemistry: The study of chemical, physical, geological and biological processes on Earth.

Bulk density: The mass of dry soil per unit volume of soil.

Genetic soil horizon: A layer of soil often occurring parallel to the soil surface that differs from adjacent soil layers in physical, chemical and biological properties or morphological features such as color, structure or roots.

Litter fall: Dead plant residues that accumulate on the soil surface annually.

Metavolcanic: Metamorphosed, igneous, extrusive bedrock.

Nitrogen cycling: The cyclical transformations and translocations of nitrogen from the atmosphere $\left(\mathrm{N}_{2}\right)$, to plant and microbial tissues, to inorganic nitrogen $\left(\mathrm{NO}_{3}\right.$ and $\left.\mathrm{NH}_{4}\right)$.

Perched water table: A discontinuous saturated zone in soil that occurs when vertically percolating water reaches a slowly permeable soil horizon.

Soil profile: An excavation in the soil approximately 3 feet long by 3 feet wide by 5 feet deep used to describe and sample soils. lands. The ability to co-locate these projects is rare and would not be possible without the support of the SFREC infrastructure and staff.

\section{A natural laboratory}

SFREC has served as a natural laboratory to study soils, ecology, hydrological processes and land management effects for many years. There is a nearly 30-year record of water flow and water quality for its Schubert watershed (Lewis et al. 2000, 2006). Schubert watershed is 255 acres in size, with tree coverage of approximately 50\%, predominantly blue oak. A similar experimental 90-acre watershed at SFREC, called Lewis-1, was instrumented in 2002. These paired watersheds are within 3 miles of each other, and are two of four watersheds at SFREC that we have been monitoring for stream flow and water quality. They were chosen because they are similar in elevation, topography, geology, soils and vegetation (type and canopy coverage). The main difference between Lewis-1 and Schubert is size, Lewis- 1 being 90 acres and Schubert, 255 acres. As part of a project beginning in 2002, Lewis-1 has been ungrazed for about 10 years, and Schubert has been heavily grazed.

In the experimental Lewis-1 watershed, we installed a weather station, 400 soil-moisture sensors, a perched water monitoring infrastructure and a streamflow monitoring network. A perched water table occurs during the rainy season above a relatively impermeable clayrich horizon situated approximately 10 inches below the soil surface. This infrastructure has allowed us to document the relationships between rainfall, soil moisture storage, lateral flow through soils and stream flow at 15-minute intervals since summer 2006 .
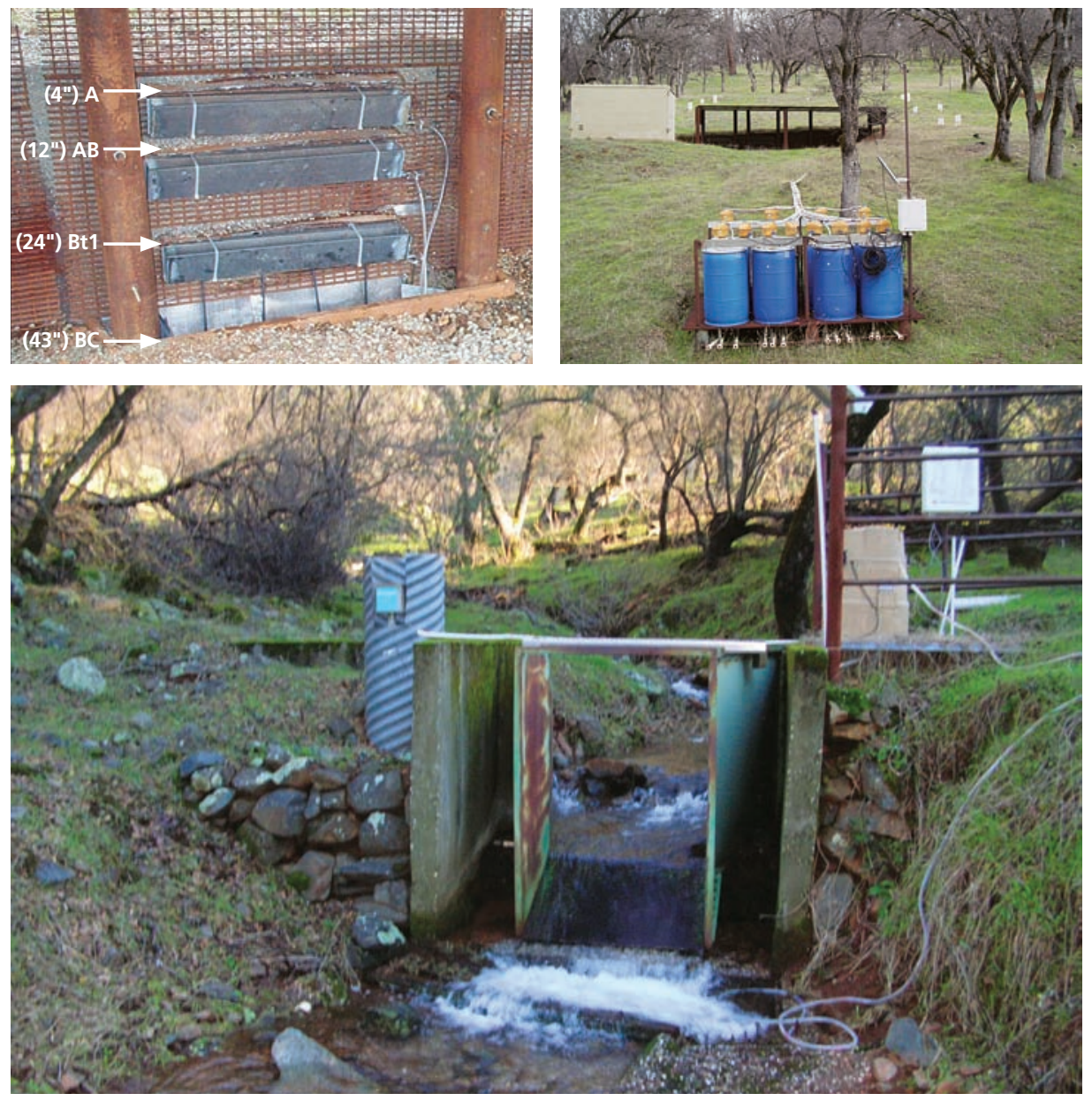

Above, the Lewis-1 watershed at SFREC was equipped with instruments in 2002 to sample and monitor the interactions between soil and stream water. Top left, a perched water monitoring trench uses trays to collect water samples from different soil horizons (A, AB, Bt1 and BC). Top right, tipping buckets are mounted on the blue containers to measure lateral water flow. 
To understand the temporal and spatial patterns in water content, sensors were placed in 100 soil profiles, typically at depths of $4,12,20$ and 40 inches. Perched water flow was monitored continuously from a trench that contained three soil profiles fitted with water-collection trays inserted at four depths: 4 inches (bottom of A horizon), 12 inches (bottom of AB horizon), 24 inches (upper boundary of the clay pan) and 43 inches (below the clay pan). Water flow rates were recorded from each layer using tipping buckets, and water chemistry samples were collected in plastic drums. Stream flow was monitored continuously using water-height sensors connected to a combination V-notch weir for measurement at lowflow conditions, and a Parshall flume was used for high-flow measurements. Automated samplers were used to collect water samples from streams on an hourly basis during storm events, and base flow was collected periodically between storms.

The soil and ecological data that we collected reflects a variety of experiments that have been conducted at SFREC over the last two decades, including at Schubert watershed. Soil profiles under the oak canopy and open grasslands were sampled by genetic soil horizon to determine the effects of oak nutrient cycling on soil characteristics. Organic matter concentrations (total carbon and nitrogen) were determined for each soil horizon, and these values were converted to an area basis using the soil bulk density, horizon thickness and rock content. Two representative blue oaks (70 and 92 years old with 11.5- and 19-inchdiameter breast heights, respectively) were destructively sampled, and all aboveground components were dried and weighed to determine the size of the carbon and nutrient pools. Root biomass and nutrient concentrations were calculated from root quantification studies conducted for these same sites (Millikin and Bledsoe 1999). To document temporal changes in soil solution chemistry, 1.5-to-1 water extracts were prepared for each soil horizon monthly to determine the concentrations of soluble nutrients in soil horizons beneath the oak canopy and in adjacent grasslands.

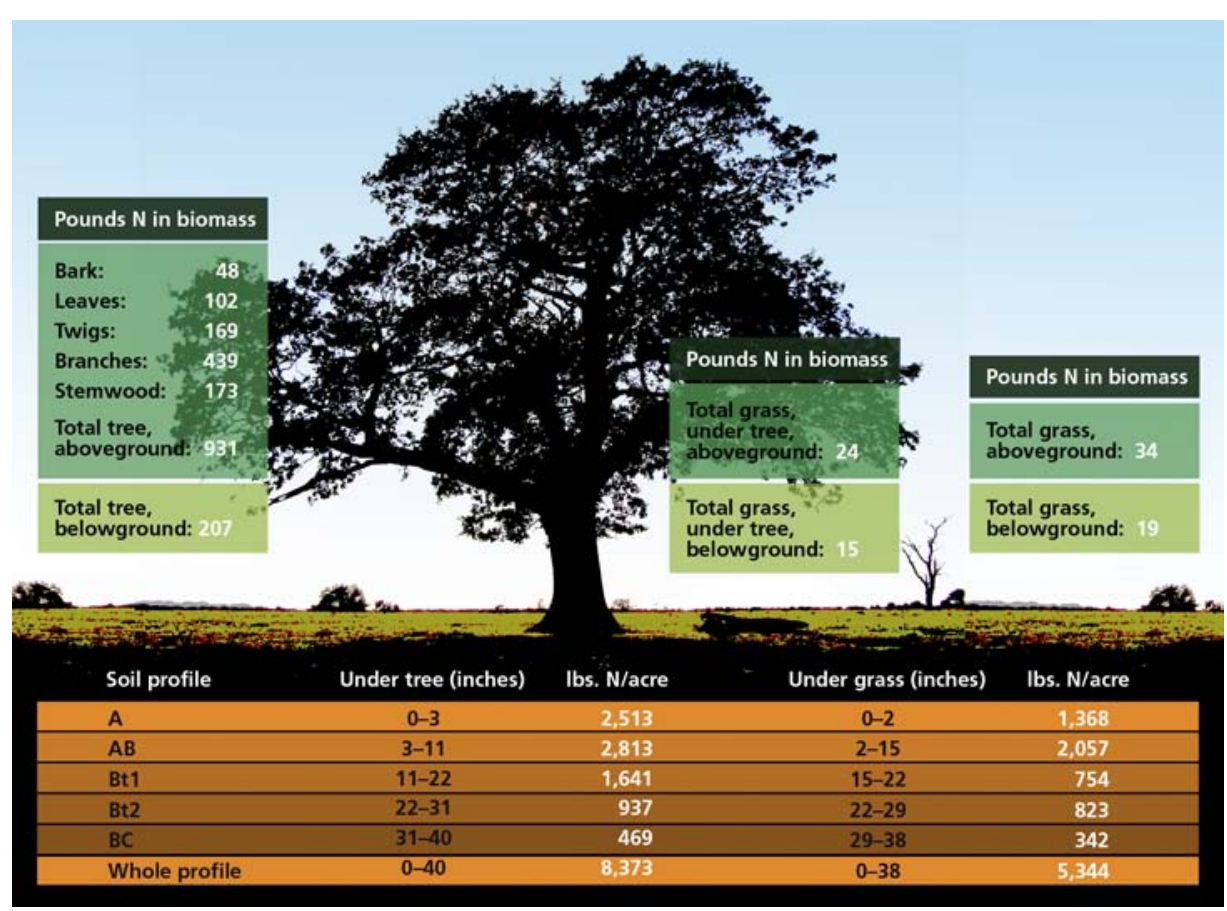

Fig. 1. Nitrogen cycling with major pools of nitrogen (pounds/acre) for an oak woodland-grassland ecosystem in the Schubert watershed at SFREC.

\section{Soil properties}

Soils at SFREC and throughout the metavolcanic terrain within the foothill region are moderately deep to very deep, ranging from 20 inches to more than 60 inches. Soils possess a distinctive red color due to the high iron content of the parent material that is released through weathering. A typical soil profile has the following genetic horizon sequence: A-AB-Bt1-Bt2-BC-Cr or R.

The $\mathrm{A}$ and $\mathrm{AB}$ horizons have a clay-loam texture and appreciable soil organic-matter enrichment. Under oak trees, A horizons are thicker (4 versus 2 inches), with higher organic matter and lower bulk density compared to those in open grasslands (Dahlgren et al. 1997). The $A$ and $A B$ horizons are porous and extensively burrowed by pocket gophers. Soils with Bt1 and Bt2 horizons represent an accumulation of clay (about 35\% to 50\%, maximum) transported from overlying horizons by percolating water. Bt horizon textures range from clay loam to clay depending on the landscape position. Claypans (Bt2) are a subset of Bt horizons that have an abrupt clay increase (more than 20\% relative to the overlying horizon) over a short vertical distance (less than 1 inch). Soil profiles containing claypans occupy less than half of the landscape area in the experimental watershed and tend to occur on level or gently sloping hillsides and land forms that accumulate water. Clay content decreases below the Bt horizons, resulting in a transition horizon (BC). The soil interface with bedrock is described by either $\mathrm{Cr}$ (soft bedrock) or $\mathrm{R}$ (hard bedrock) horizons.

\section{Nitrogen cycling}

Nitrogen cycling within the landscape is directly linked with the oak canopy distribution and hydrologic cycle. The majority of nitrogen is present as soil organic matter stored in the $\mathrm{A}$ and $\mathrm{AB}$ horizons (approximately the upper 15 inches of soil). We found that the major nitrogen pool is contained in soil profiles under oak trees at about 8,373 pounds per acre (fig. 1 ). The nitrogen pool contained within the oak trees was approximately $14 \%$ of the total soil nitrogen pool. Nitrogen stored in blue oak was about 1,138 pounds per acre (931 aboveground plus 207 pounds per acre in roots belowground), while understory components (e.g., grasses and herbs) added 39 and 53 pounds per acre under the oak canopy and in open grasslands, respectively. The soil nitrogen pool was nearly 1.6 times greater ( 8,373 versus 5,344 pounds per acre) in 


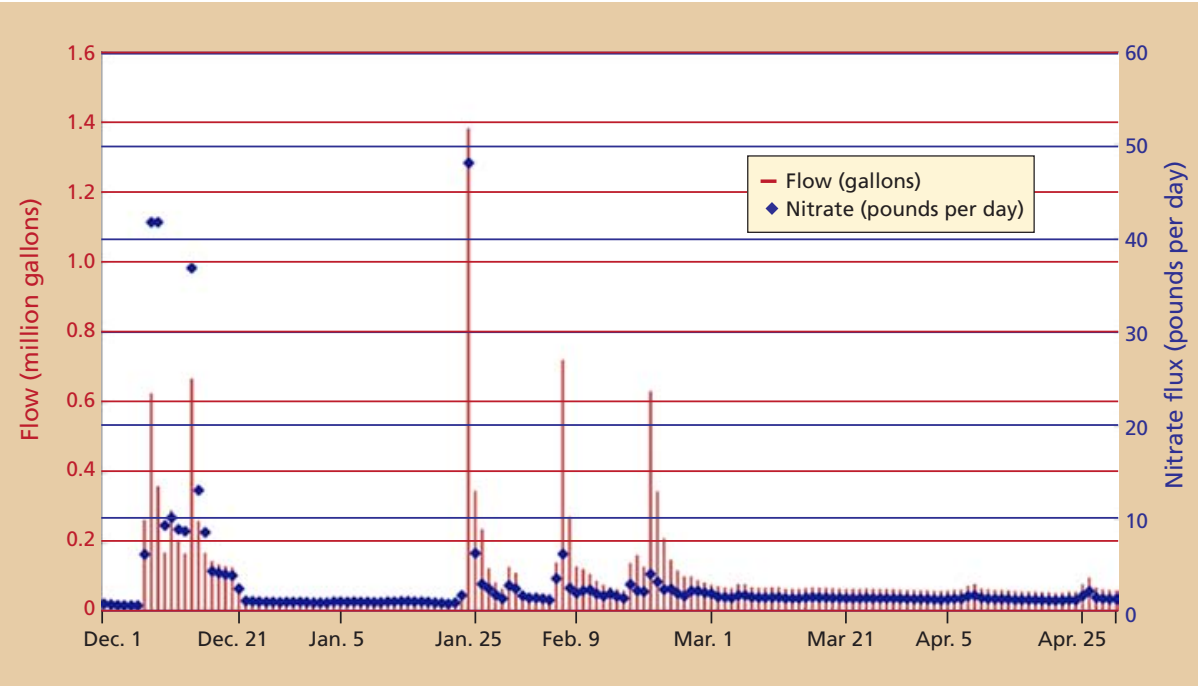

Fig. 2. Stream flow and nitrate-nitrogen $\left(\mathrm{NO}_{3}-\mathrm{N}\right)$ load in the 1992-1993 water year, Dec. 1 through April 30, at the Schubert watershed.

soils beneath the oak canopy compared to open grasslands (fig. 1).

Organic matter. The ability of oaks to alter their soil environment occurs primarily through the addition of organic matter and nutrient cycling. During a 3-year (1990-1992) study period, oaks returned about 4,008 and 75 pounds per acre annually of organic carbon and nitrogen, respectively, to the soil surface through aboveground litter fall. Belowground carbon inputs through oak and annual grass root turnover also contributed an appreciable amount of organic matter (Jackson et al. 1990; Millikin and Bledsoe 1999). An additional 5.3 pounds per acre of nitrogen was added annually to the soil surface by canopy throughfall (canopy drip) and stem flow (water flowing down the tree trunk). Nutrient flux in the canopy throughfall originates from the capture of atmospheric aerosols, gases and par-

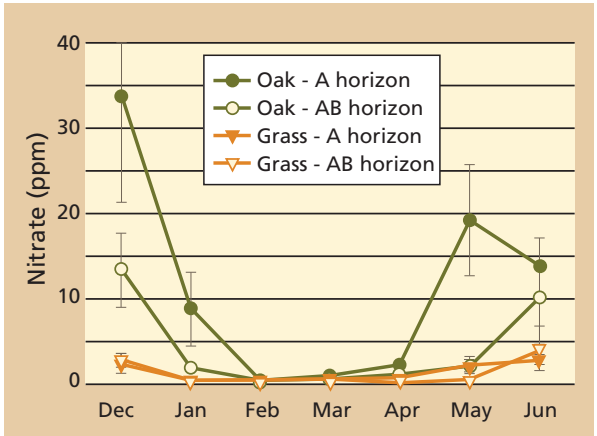

Fig. 3. Nitrate-nitrogen $\left(\mathrm{NO}_{3}-\mathrm{N}\right.$, parts per million) concentrations in soil pore water under oak canopy and open grassland. ticulate matter, as well as from root uptake with subsequent foliar leaching.

Roots. In addition, oaks are rooted considerably deeper than annual grasses, which reduces deep leaching and the loss of nutrients beneath the oak canopy. About 70\% of the oak root biomass occurs within the upper 20 inches of the soil profile (Millikin and Bledsoe 1999). Oak roots also extend well beyond the edge of the canopy, where they can sequester nutrients from grassland soils. Over time, they concentrate these nutrients beneath the oak canopy in the form of litter fall and canopy throughfall. Given the organicmatter enrichment in soils and oak vegetation, there is considerable potential for carbon sequestration (about 89 tons per acre) associated with the conversion of grasslands to oak woodlands. To ensure long-term carbon sequestration, oak trees must be protected. Organic carbon and many of the enhanced soil properties are lost within 20 to 30 years following an oak's removal (Dahlgren et al. 2003).

Climate and seasons. The Mediterranean climate contributes to strong spatial and seasonal patterns in soilsolution and stream nutrient concentrations, as illustrated by nitrate concentrations during the winter/ spring rainy season (figs. 2 and 3). Peak soil-solution nitrate concentrations occur in fall and late spring and are considerably higher in soils under oak canopy during these times (fig. 3).
In contrast, nitrate concentrations are very low and similar between oak and open-grassland soils during the winter months when soil moisture storage and leaching are at their peaks, and soil temperatures and microbial activity are low.

In addition, annual grass growth and oak foliage production results in strong demand for biological nutrients in spring, further depleting the soil nitrate pool in spite of favorable moisture and temperature conditions for microbial mineralization. The increase in soil nitrate in late spring coincides with the senescence (die off) of annual grasses, which results in a decrease in nitrogen uptake demands coupled with the release of nitrogen from dead annual grass roots by microbial decomposition. Dry conditions in the upper soil profile throughout summer result in low nitrogen uptake by oak roots.

Instead of continuous nitrogen feedback among senescing plants, their soils and new growth, nitrogen is mineralized and accumulates in soils during the dry summer and fall months (Hart et al. 1993). Throughout summer, organic and inorganic nitrogen accumulates in the soil, and there is little plant growth to sequester these nutrients. Early fall rains (September to October) cause the leaching of ammonium, nitrate and dissolved organic nitrogen (DON) from annual grass residues (more than $50 \%$ of total DON) while senescent oak foliage accounts for more than $70 \%$ of total DON after the first storm (Chow et al. 2009). High concentrations of DON combined with water availability and warm residual soil temperatures lead to an explosion of microbial activity that results in rapid nitrogen mineralization and the accumulation of nitrate in the upper soil horizons.

An asynchrony within nutrient cycles occurs in the Mediterranean climate, causing a marked nitrate spike in stream water during the onset of the rainy season (December to January) (Holloway and Dahlgren 2001). Nitrate leaching from oak woodland watersheds at SFREC is strongly linked to the hydrologic cycle at time scales ranging from storm events (hours) to years. Pulses in stream nitrate concentrations are observed that match those observed 
in soil pore water in the fall. Each storm progressively flushes this nitrogen pool, so that by March there is little nitrate found in soils and stream water (figs. 2 and 3).

\section{Hydrologic flow paths}

Stream flow and water quality are related to soil water storage and hydrologic flow paths through soils. Our conceptual model of the dominant hydrologic flow path in soils of this area is lateral, perched water flow through the upper soil layers (A and AB horizons) following watershed priming. Approximately 7 to 10 inches of precipitation are required to bring the watershed soils to their maximum water-holding capacity before stream flow generation begins (Lewis et al. 2000). With the onset of winter storms, water infiltrates and percolates through the highly permeable $\mathrm{A}$ and $\mathrm{AB}$ horizons. The vertical percolation of water is impeded by the presence of the claypan approximately 24 inches below the soil surface. The claypan is slowly permeable to water, and as a result saturated conditions develop at the upper boundary of the claypan during storms. A saturation zone (perched water table) forms at the claypan boundary and extends upward into the $\mathrm{A}$ and $\mathrm{AB}$ horizons as precipitation continues. Once they are saturated, water moves with the force of gravity (down slope) through the highly permeable $\mathrm{A}$ and $\mathrm{AB}$ horizons, rapidly delivering water as lateral flow to streams.

Storm events. The hydrologic monitoring infrastructure within the experimental watershed demonstrated the connectivity of lateral flow in soils with stream flow during a typical storm (fig. 4). The timing of stream and perched water flow during the course of a storm was similar. Peak stream flow was sustained for approximately 3 hours from 7 p.m. to 10 p.m. during a storm in January 2007 and corresponded with the initiation of lateral flow through the $\mathrm{AB}$ horizon located above the claypan. Perched water flow through the AB horizon was the dominant flow path. During this storm event the $\mathrm{AB}$ horizon delivered $60 \%$ of the total water volume, measured from the perched water monitoring infrastructure. The other horizons contributed relatively equal water volumes ranging from $10 \%$ to $17 \%$ (fig. 5). An additional line of evidence is apparent from the slope characteristics associated with the rising limb of the hydrographs, where the stream and $A B$ horizon have nearly identical slopes, suggesting that the rapid increase in stream flow is a result of water transport through the AB horizon (fig. 4).

The AB horizon supplied more water to the stream for a variety of reasons. The AB horizon is more permeable than the Bt and BC horizons, because it contains less clay, better soil structure and more large pores (e.g., gopher burrows and decayed root channels)

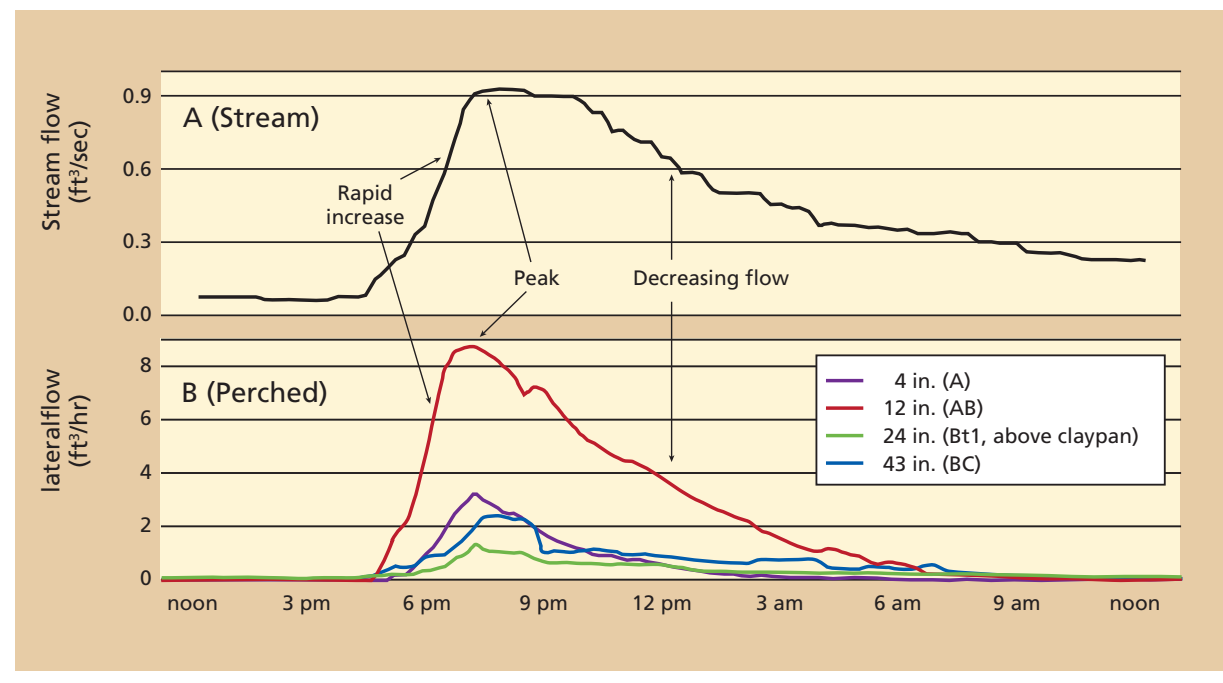

Fig. 4. (A) Stream and (B) perched water hydrographs during the first stream flow event of 2007.

to conduct water rapidly. While the permeability of the $\mathrm{AB}$ horizon is similar to that of the A horizon, the $\mathrm{AB}$ horizon supplied more water because it was saturated longer due to its proximity to the underlying waterrestrictive clay layer. The delay in flow of the $A$ relative to the $A B$ horizon represents the time it took for the perched water table to extend upward into the A horizon. The AB horizon is also thicker than the A horizon (8 versus 4 inches), resulting in a greater cross-sectional area to deliver water.

Water quality. The hydrologic flow paths through soils at SFREC directly affect water quality. With their permeable nature, surface horizons convey water rapidly to streams in large volumes. Infiltration rates range from 1 to 4 inches per hour, and as a result, surface runoff is rare when soils are not saturated (Lewis et al. 2000). Because plants are not actively transpiring during the rainy season, the soil water-storage capacity is frequently exceeded, which results in the transport of water via

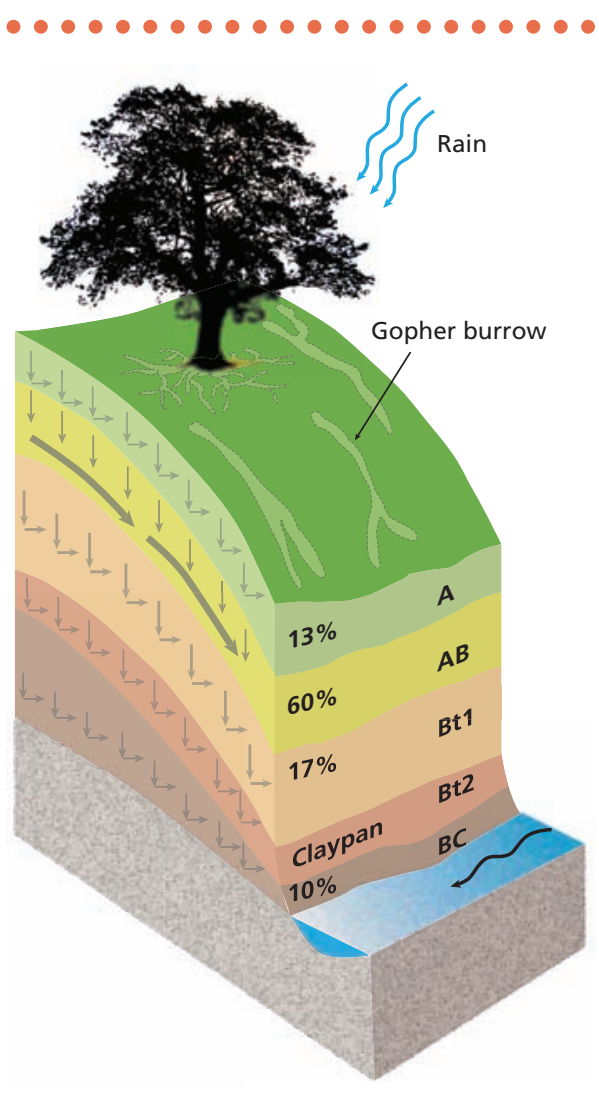

Fig. 5. Contribution of hydrologic flow paths in soils at SFREC. Percentages refer to the total lateral flow contributed by each soil layer during a typical storm event. 


\section{More than two-thirds of California's drinking-water supply passes through or is stored in oak woodlands.}

lateral flow through the nutrient-rich $\mathrm{A}$ and $\mathrm{AB}$ horizons, directly to the stream. The nitrate accumulated in the $\mathrm{A}$ and $\mathrm{AB}$ horizons is susceptible to leaching because little plant uptake occurs during the winter months. The shift to laterally dominated flow paths during storms results in elevated nitrogen concentrations in stream water as nitrate, which is leached directly to the stream via lateral subsurface flow through the $A$ and $A B$ horizons (figs. 4, 5 and 6). In contrast, elements that are associated with groundwater and chemical weathering in the lower Bt and BC horizons (e.g., calcium and sodium) display a

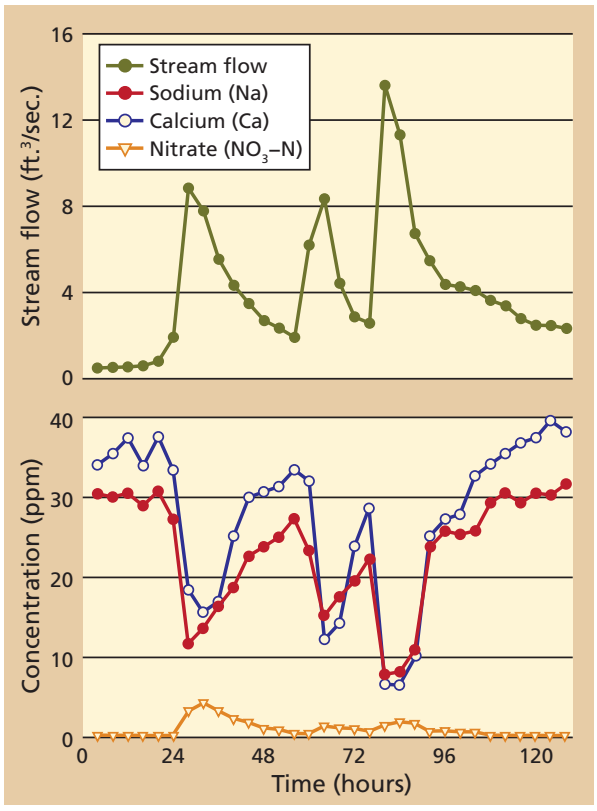

Fig. 6. Changes in stream water chemistry during an early-season (Jan. 2007) storm event.

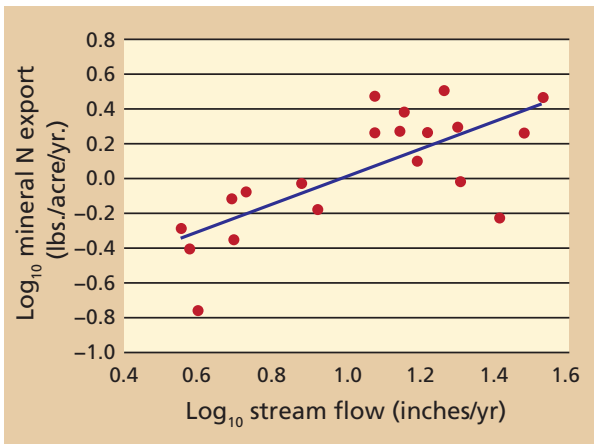

Fig. 7. Relationship of stream nitrate fluxes and stream flow volume (water flux) for a 20-year period (1981-2000) in the Schubert watershed at SFREC; $r^{2}=0.52 ; P<0.001$. distinct decrease in concentration during storms as the hydrologic flow path is short-circuited through the upper soil horizons (fig. 6).

Nitrate variability. There is considerable year-to-year variability in nitrate leaching from oak woodland watersheds (fig. 7). The mean annual nitrate-nitrogen $\left(\mathrm{NO}_{3}-\mathrm{N}\right)$ export from the Schubert watershed was 1.4 pounds per acre annually (ranging from 0.16 to 3.2 pounds per acre annually) (Lewis et al. 2006). While annual nitrate-nitrogen flux at Schubert reached values as high as 3.2 pounds per acre annually, the loss of nitrate-nitrogen from the watershed was substantially less than atmospheric inputs of mineral nitrogen (ammonium $\left[\mathrm{NH}_{4}\right]$ plus nitrate $\left.\left[\mathrm{NO}_{3}\right]\right)$ in the bulk precipitation (mean 8.4 pounds per acre annually). As a result, there was a net retention of mineral nitrogen within the Schubert watershed, assuming no loss of nitrogen through denitrification or volatilization. The annual nitrate-

nitrogen load was positively and significantly $(P<0.05)$ related to both annual precipitation and stream flow (Lewis et al. 2006). Nitrate fluxes were a function of total stream flow volume and the timing of storm-flow events throughout the season. Years with high rainfall and runoff, combined with high runoff during the early portion of the rainy season - when nitrate concentrations are highest in the soil profile - resulted in the largest fluxes of nitrate-nitrogen from the watershed.

Differences in stream nitrate flux (figs. 2 and 6) can also be explained by the extent of the perched water table within the watershed and its connectivity to the stream. The observed variation in stream nitrate flux is a result of flushing of the $\mathrm{A}$ and $\mathrm{AB}$ horizons by the lateral flow path, because these horizons contain most of the nitrogen. The degree of flushing is a function of the amount and intensity of rainfall, the seasonal distribution of rainfall, the spatial extent of the claypan, and the soil moisture content prior to a storm event.

Perched water table. Figure 8 shows the extent and connectivity of the perched water table within the

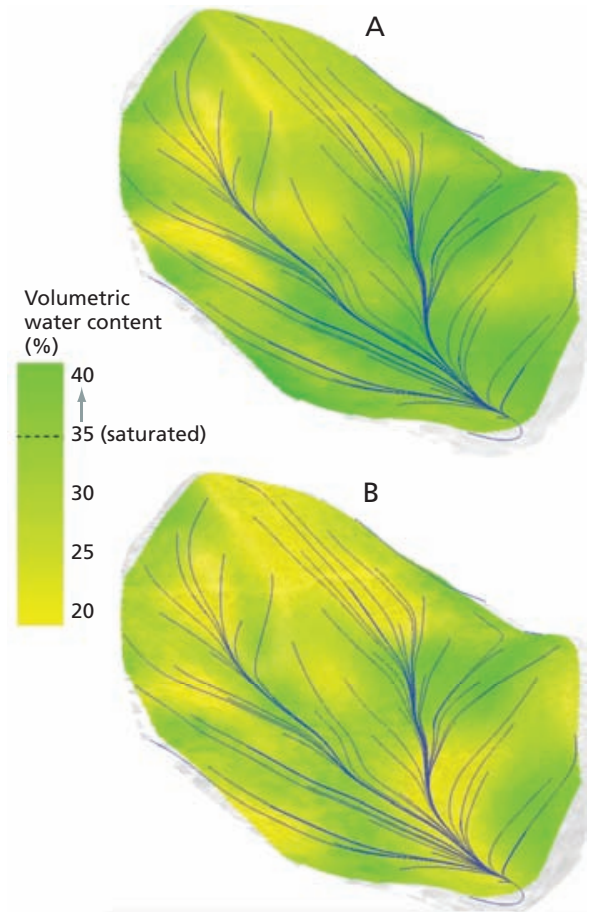

Fig. 8. Extent of saturated conditions in the experimental watershed within the $A B$ horizon during peak flow of two storm events: (A) Jan. 4 and (B) Feb. 27, 2008. Saturated conditions are depicted in green where water content is $35 \% \pm 3 \%$.

$\mathrm{AB}$ horizon as indicated by saturated conditions (water content greater than $35 \%$ ) during peak stream flow for two storms: (A) Jan. 4, with a large stream nitrate concentration and (B) Feb. 27, with a low stream nitrate concentration. The spatial extent of the perched water table was $59 \%$ of the watershed area during the first storm (fig. 8A) compared to $36 \%$ during the second storm (fig. 8B). The perched water table was connected to the stream, as indicated by the overlap of regions shaded in green with blue flow lines, which were generated from a digital elevation model to predict the routing of water by topography, using the slope and curvature of the landscape (fig. 8).

The perched water table during the second storm occupied isolated areas with less connectivity to the stream, as indicated by areas of yellow (unsaturated) and green (saturated) intersecting the blue flow lines (fig. 8B). This suggests that the dominant source area of stream flow was limited to the center of the watershed during the Feb. 24 storm, when saturated conditions coin- 


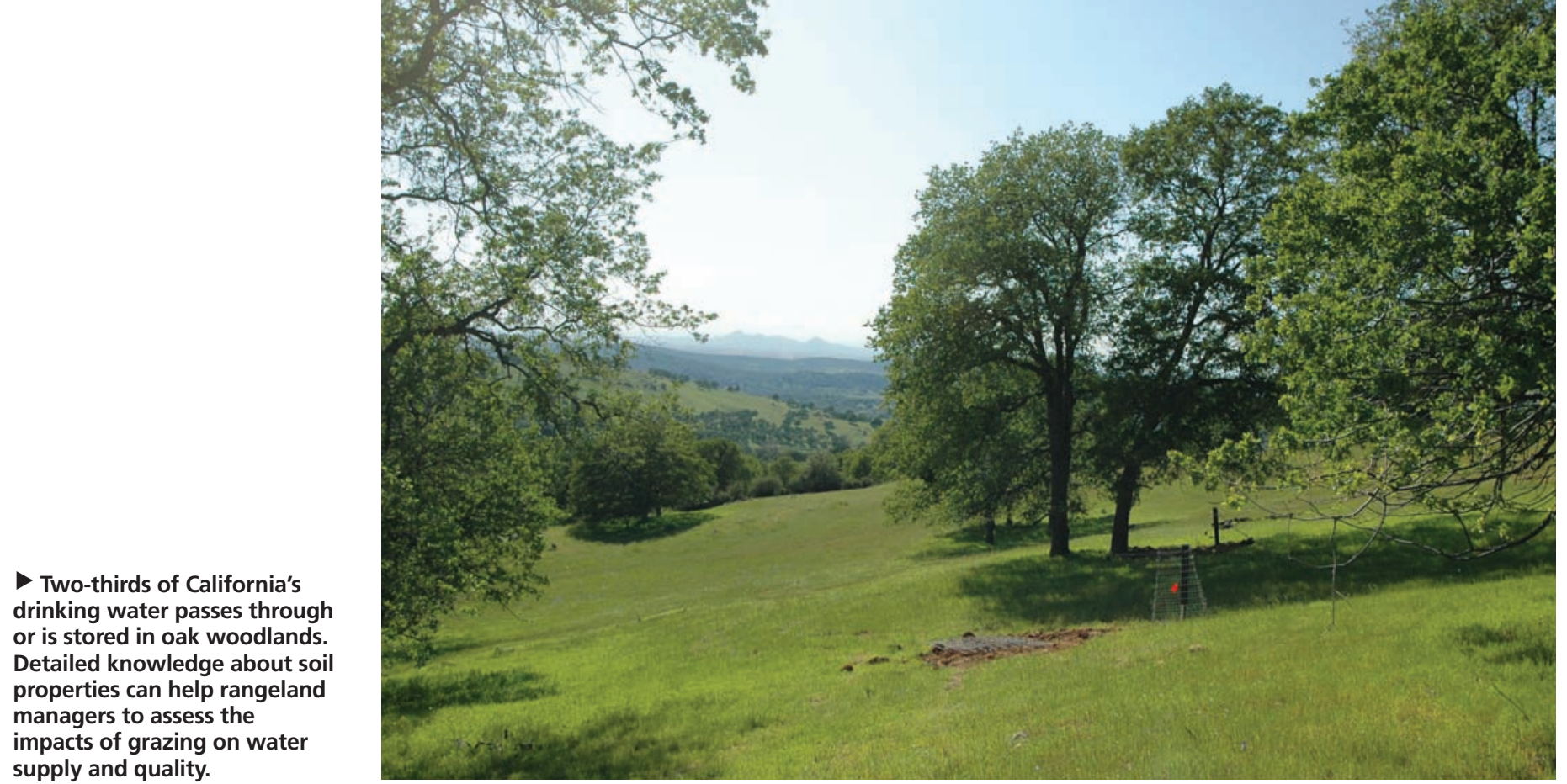

cided with the main flow lines. Thus, variation in nitrate flux observed over a season (figs. 2 and 3) and during a storm (fig. 6) is a result of the sequential flushing of nitrate from the soil over time and the area of the watershed that is leached, determined by the spatial extent of the perched water table and its connectivity to streams.

\section{Soils and rangeland management}

More than two-thirds of California's drinking-water supply passes through or is stored in oak woodlands. Despite the seasonal peaks in nitrate in streams at SFREC, the concentrations are low relative to drinking-water standards (10 parts per million [ppm] nitratenitrogen). However, the temporal and spatial patterns between soils and streams observed in this study are relevant to understanding how soils affect water supply and its quality, and can help to guide rangeland management practices such as the stocking rate, season and location of livestock congregation activities (supplemental feeding stations).

In some instances, the variability of soil properties at SFREC and in the Sierra Foothill region exceeds our ability to document them at scales relevant to rangeland management. Key soil properties, however, such as the distribution of claypans, should be documented by soil surveys in order to understand the spatial connectivity of hydrologic-transport processes (surface runoff, subsurface flow, stream flow) within watersheds. Currently, California's soil surveys in rangelands are not mapped at scales fine enough to portray these soil features across landforms and their connectivity to streams. It is important that stakeholders communicate this concern to the U.S. National Cooperative Soil Survey to focus soil survey updates in these important landscapes. This level of detail is warranted to better understand patterns in oak regeneration, perennialgrass restoration, forage productivity, rainfall-to-runoff characteristics and water-quality dynamics.

\footnotetext{
A.T. O'Geen is Associate Soil Resource Specialist in Cooperative Extension, and R.A. Dahlgren is Professor of Soil Science, Department of Land, Air and Water Resources, UC Davis; A. Swarowsky is Graduate Student, Soils and Biogeochemistry Graduate Group, UC Davis; K.W. Tate is Rangeland Watershed Specialist in Cooperative Extension, Department of Plant Science, UC Davis; D.J. Lewis is UC Cooperative Extension Advisor and County Director, Marin County; and M.J. Singer is Professor of Soil Science, Department of Land, Air and Water Resources, UC Davis. We thank all the staff at SFREC who supported this research over the past 30 years. This research was supported in part by the UC Integrated Hardwood Range Management Program, UC Kearney Foundation of Soil Science, UC Division of Agriculture and Natural Resources, Russell L. Rustici, USDA, USDA Cooperative State Research, Education, and Extension Service, and State Water Resource Control Board.
}

\section{References}

Chow AT, Lee S, O'Geen AT. 2009. Litter contributions to dissolved organic matter and disinfection byproduct precursors in California oak woodland watersheds. J Env Qual. 38:2334-43.

Dahlgren RA, Horwath WR, Tate KW, Camping TJ. 2003. Blue oak enhance soil quality in California oak woodlands. Cal Ag 57(2):42-7.

Dahlgren RA, Singer MJ, Huang X. 1997. Oak tree grazing impacts on soil properties and nutrients in a California oak woodland. Biogeochemistry 39:45-64.

Hart SC, Firestone MK, Eldor PA, Smith JL. 1993. Flow and fate of soil nitrogen in an annual grassland and a young mixed-conifer forest. Soil Biol Biochem 25:431-42.

Holloway JM, Dahlgren RA. 2001. Seasonal and event-scale variations in solute chemistry for four Sierra Nevada catchments. J Hydrol 250:106-21.

Jackson LE, Strauss RB, Firestone MK, Bartolome JW. 1990. Influence of tree canopies on grassland productivity and nitrogen dynamics in deciduous oak savanna. Agric Ecosyst Env 32:89-105

Lewis D, Singer MJ, Dahlgren RA, Tate KW. 2000 Hydrology in a California oak woodland watershed: A 17-year study. J Hydrol 240:106-17.

Lewis DJ, Singer MJ, Dahlgren RA, Tate KW. 2006. Nutrient and sediment fluxes from a California rangeland watershed. J Env Qual 35:2202-11.

Millikin CS, Bledsoe CS. 1999. Biomass and distribution of fine and coarse roots from blue oak (Quercus douglasii) trees in northern Sierra Nevada foothills of California. Plant Soil 214:27-38. 